\title{
A Study of Relationship between Achievement Motivation, Self Concept and Achievement in English and Mathematics at Secondary Level
}

\author{
Dr. Riffat-Un-Nisa Awan \\ Assistant Professor, Department of Education \\ University of Sargodha, Pakistan \\ E-mail: riffatawan@uos.edu.pk
}

Dr. Ghazala Noureen

Assistant Professor, Department of Education

Lahore College for Women University, Lahore, Pakistan

E-mail: g_noureen@yahoo.com

Ms. Anjum Naz

Lecturer, Department of Education, University of Sargodha, Pakistan

E-mail: anjumnaz@hotmail.com

Received: January 10, 2011 Accepted: February 14, 2011 doi:10.5539/ies.v4n3p72

\begin{abstract}
This study examined the achievement and its relationship with achievement motivation and self concept. The subjects consisted of 336 students (146 males and 172 females) from four public and four private schools of the Sargodha district at the secondary level. Intact groups of all eight schools enrolled in $9^{\text {th }}$ grade were involved in the study. An Urdu translated version of 'Academic Self-Description Questionnaire II' (Marsh, 1990) and 'General Achievement Goal Orientation Scale' (McInerney, 1997) was used. The results revealed that achievement motivation and self concept are significantly related to academic achievement. Significant gender differences were discovered which were in favor of girls. It was suggested that teachers must use motivational strategies to involve students in academic activities for improving their grades.
\end{abstract}

Keywords: Achievement Motivation, Achievement, Self Concept, Mastery Goals, Performance Goals, Social Goals

\section{Introduction}

Motivation is generally defined as internal condition that stimulates, direct and maintains behavior. There is a strong relationship between learning and motivation. According to Abraham Maslow when the need for love and belongingness are met, individual can then focus on higher level needs of intellectual achievement. At this stage urge to learn increases (Woolfolk, 2004). Motivating students to learn in school is a topic of great concern for educationist today. Motivating students so that they can succeed in school is one of the greatest challenges of this century. Lack of motivation is a big hurdle in learning and a pertinent cause in the deterioration of education standards. According to Deci and Ryan (2000) motivation is greatly appreciated because of the consequences it produces. The attitude that is often used in conjunction with motivation to achieve is self concept, or the way one thinks about oneself to perform a task successfully. There is considerable evidence to support the contention that positive academic self-concept contributes to academic achievement by enhancing the motivation to achieve. This study's purpose is to explore student achievement motivation, their self concept and how these factors impacts learning and achievement.

\subsection{Achievement Motivation}

Need for Achievement (nAch) (McClelland, 1961; McClelland \& Winter, 1969) is one of the psychological motives that play an important role in success and achievements of a man. Motivation as an academic engagement refers to "cognitive, emotional, and behavioral indicators of student investment in and attachment to education" (Tucker, 
Zayco, \& Herman, 2002, 477). Achievement motivation has been defined as the extent to which individuals differ in their need to strive to attain rewards, such as physical satisfaction, praise from others and feelings of personal mastery (McClelland, 1985). People with high achievement motives will act in ways that will help them to outperform others, meet or surpass some standard of excellence, or do something unique (Schmidt \& Frieze, 1997, 427). All students are influenced by a need to achieve to a certain degree. Those students, who hold a high desire of success, work hard to achieve (Zenzen, 2002, 10).

The modern study of achievement motivation began with the work of David McClelland. He and his associates coined the term $\mathrm{n}$ Ach denoting need for achievement (McClelland, 1961; McClelland \& Winter, 1969). This theory says that under appropriate conditions, people will do what they have been rewarded for doing. Weiner (1986) has presented the most ambitious attribution theory of achievement motivation and emotions. This theory deals with the perceived causes of success and failure, the characteristics of causal thinking, and subsequent emotional experiences in relation to achievement behaviors. Another important leap in motivational research is goal orientation theory. The basic premise of achievement goal orientation theory (Elliot and McGregor, 2001) is that when students engage in academic tasks, they set various personal goals and the types of goals that students adopt can directly influence their academic outcomes.

Elliot and McGregor's (2001) model of achievement motivation, discuss two broad classes of goals: mastery goals i. e. to "master" the task at hand and performance goals i.e. demonstrating superior performance relative to others. Research indicates that when students adopt mastery goals, they tend to engage in more effective cognitive processing strategies (Noar, Anderman, Zimmerman, and Cupp, 2005). Social goals are another important type of goals, although not examined at length as mastery and performance goals (Dowson \& McInerney, 2001). In these goals social reasons are the main concerns for trying to achieve in academics. According to Maehr $(2008,918)$ achievement motivation is largely social psychological in nature. It often occurs within groups, where interpersonal interactions can undermine or facilitate engagement in the tasks to be done.

\subsection{Academic Self-concept}

Self concept is a person's self perception. It may be understood as individuals' feelings or confidence levels in accomplishing particular academic tasks. Chowdhury, and Pati, $(1997,135)$ assert that 'self-concept plays a significant role in the educational process when a child is accepted, approved, respected and liked ---- one will have an opportunity to acquire an attitude of self-acceptance and respect for one self'. According to Wang and Lin (2008) self-concept was seen as the general confidence that individuals felt about themselves and the levels of an individual's self-concept predict whether or the extent to which he or she was able to accomplish academic tasks successfully or unsuccessfully. They further quote Byrne that much of the earlier interest in the self-concept versus achievement relationship stemmed from the belief that academic self-concept had motivational functions and thus, changes in academic self-concept would lead to changes in subsequent academic achievement.

Decades of research on self concept have contributed significantly as well as independently to our understandings of how critical students' appraisals of themselves can be for their successful functioning and well-being in school (Bong, and Clark, 1999). This self-construct has been particularly beneficial when used to predict or explain students' motivation and achievement. A substantial body of literature indicates that self-concept is related to academic performance. Moderate to strong relations between academic achievement and academic self-concept has been found in a large proportion of research (Abouserie, 1995; Chowdhury \& Pati, 1997; Collins, Hanges, \& Locke, 2004; Wang \& Lin, 2008).

Abouserie (1995) gives evidence that self-concept and achievement motivation are correlated and his analysis suggests that self-concept makes a positive contribution to students' scores on deep processing. Achievement motivation contributes positively to students' scores on achieving orientation, meaning orientation and methodical study. Findings of many studies (Abouserie, 1995; Tella, 2007; Broussard, 2002; Wilkins, 2006) suggest that achievement motivation and self concept are directly and indirectly related to academic achievement. Highly motivated students perform better academically than the lowly motivated students (Tella, 2007). Therefore the students' personality variables in general and self-concept and achievement motivation in particular, have a substantial influence on their approaches to study.

Academic achievement refers to particular learning in a particular setting which is defined by examination marks, teachers' given grades and percentiles in academic subjects (Chowdhury, and Pati, 1997, 138). School success depends upon the ability of the students to qualify such examinations. For present study Academic Achievement is defined as that which is indicated by the total marks in English and mathematics subject obtained by the pupil out of 100, in the final examinations conducted by the Board of Intermediate and Secondary Education (BISE) Sargodha, 
during the year 2009. The purpose of this research study is to examine relationship among achievement motivation, academic self-concept and academic achievement of the student at the secondary school level in district Sargodha.

The main objectives of this study are:

i. To find out the relationship between achievement motivation, self concept and academic achievement.

ii. To investigate gender differences for achievement motivation, self concept and academic achievement.

\section{Method}

Sample: The subjects consisted of 336 students (146 males and 172 females) from four public and four private conveniently selected schools of the Sargodha district at the secondary level. Intact groups of all eight schools enrolled in $9^{\text {th }}$ grade were involved in the study. The following instruments were used: I. Academic Self-Description Questionnaire II (ASDQ II) (Marsh, 1990) for measuring self concept in English and self concept in Mathematics; II. General Achievement Goal Orientation Scale (GAGOS) (McInerney, 1997) for measuring three types of achievement goals i.e. mastery goals, performance goals and social goals.

The questionnaire was translated into Urdu language and was finalized keeping in view the suggestions and opinions of the experts for content validity. The instrument was pilot tested with 32 students for establishing its reliability. The reliability measures (Cronbach Alpha) for all five variables ranged from 0.831 to 0.613 . Pearson $r$ and $t$-test was used for correlations and mean differences using SPSS.

\section{Results}

i. The correlations of the self concept of English and mathematics and all three dimensions of achievement motivation and Academic achievement of mathematics are significant at the 0.01 level (2-tailed). The relationship among achievement of English and mathematics and three variables of achievement motivation is also significant (see table 1).

ii. Regression Analysis for self concept and achievement motivation as Predictor of academic achievement in mathematics resulted in R-Square of .381 , which implies that the self concept and achievement motivation accounted for 37 percent of the variation in achievement of mathematics.

iii. Regression Analysis for self concept and achievement motivation as Predictor of academic achievement in English resulted in R-Square of .242, which implies that the self concept and achievement motivation accounted for 24 percent of the variation in achievement of English.

iv. The mean gender difference for self concept of English is significant at 0.01 level of significance. This difference is in favour of girls having strong self perceptions as compared to boys. Self concept for Mathematics is also significant and again in favour of girls. The gender differences for performance goals and mastery goals are also significant but non-significant for social goals.

v. In terms of Academic achievement in English and mathematics the mean differences for both the variables are significant because there are significant gender differences in all the variables except social goal so it is concluded that there is a significant difference in self concept of English and mathematics, Academic achievement and performance goals and mastery goals of male and female students.

\section{Discussion}

The results of this research study depict the strong correlation among the three variables i.e. self concept, achievement motivation (social, mastery, and performance goals), and academic achievement. Results show that the subject specific self concept of students and achievement motivation (social, mastery, performance goals) are significantly correlated with each other. The results of the study are quite similar to those searched by other psychologist and researchers like Barker, McInerney, and Dowson (2003) who found positive and statistically significant correlation between the two variables i.e. self concept and achievement motivation. Regarding achievement motivation, academic self-concept is the dominant predictor in Ommundsen, and his colleagues' (2005, 470) study. Similarly self-concept had a substantial effect on motivational orientation in Zanobini, and Usai's study (2002).

It is also found out that the correlation between self concept and academic achievement was significant. Self concept was significantly related to achievement of mathematics. Marsh et al., (1999) suggest mutual enforcement between mathematics achievement and self-concept. While Ma and Kishor (1997) noted that the reciprocal link between mathematics achievement and self-concept is much weaker. The attitude of parents (Wang \& Lin, 2008), peers (Chowdhury, and Pati, 1997) and teachers is a big determent of their positive self concept and vice versa for the low 
achievers. This finding makes the importance of this critical fact clear that self concept is very vital for improving the achievement level of low achiever students.

The relationships among three variables of achievement motivation and achievement of English are positive and significant. Same is the case with achievement of mathematics and achievement motivation. Results do accord with Abouserie (1995) who point out that a significant positive correlation between students' achievement motivation and their scores on comprehension learning, meaning orientation, and methodical study was found, which suggest that students with high achievement motivation are likely to adopt deep and elaborative approaches in their English readings. This finding is also consistent with Broussard (2002) who states that higher levels of mastery motivation are found to be related to high achievement in third graders and first graders. In Bernardo's study (2008) mastery and performance goals were positively associated with academic achievement, personal performance standards, and parent-oriented achievement motivation. In a meta-analysis of the relationship between achievement motivation and performance and career choice a significant correlation is found (Collins, Hanges, and Locke, 2004). Many of the researchers have concluded that students' achievement motivation have positive effects upon their scores and subject's achievement motivation enables them to be more organized in their studies (Abouserie, 1995; Akbaş \& Kan 2007; Tella, 2007). In short, the achievement motivation contributes to enhance achievement level. Therefore, it could be suggested that motivation have an important effects on academic achievement, and also is important components of educational and instructional processes.

There are significant gender differences in the mean scores of students' self concept. The findings of the study reveal that female students have more positive self concept both about English and mathematics as compared to male students. This finding is consistent with the results of Dai et al. (1998) who found girls reporting higher confidence in English than boys.

In Dai and his colleagues' study the boys have been found to have higher self-perceptions of their mathematics ability than girls but this was not the case in this research as females were more confident about mathematics as compared to boys. Sullivan (2009) study also provides similar results which tell us that boys had higher self-concepts in mathematics and science, and girls in English. In particular situation of Pakistan the performance of girls is always better than boys in the results of all intermediate and secondary boards of the Punjab therefore the results are contradictory with the previous researches with regard to mathematics. Moreover this study also found that achievement motivation of girls was better than boys. The overall findings of Hotulainen \& Schofield (2003) indicate the same fact that girls and boys have somewhat different achievement motivations, with girls being less influenced by school-related variables in the formation of their overall sense of self. The gender differences are significant for mastery goals and performance goals but non-significant for social goals although it was still in favour of girls. This result correspond to Fontayne, Sarrazin, and Famose, (2001) findings concerning the gender variable, for the mastery goal the boys obtain a lower score on this goal than the girls although this difference between girls and boys was in the expected direction, but was non-significant.

In terms of academic achievement in English and mathematics the mean differences for both the variables are significant and are in favour of girls which means that girls have better academic achievement than boys. Girls have been found by several studies to be more motivated and higher achievers than boys. Hotulainen \& Schofield (2003) explains the same results in his study that girls were found to generally outperform boys and that boys consistently returned lower levels of perceived academic self-competence and lower GPAs than their female counterparts.

\section{Conclusion and Recommendations}

It is concluded that that positive self concept and self perception does improve the motivation level of students which consequently increase achievement levels. It is also concluded that male students are lagging behind in their level of motivation and achievement and they also have less positive self concept as compared to girls. The findings reported in this study justify the importance of motivation to academic performance and of self concept and achievement. The findings have implications for the teachers of English and mathematics that they should focus on and carry out motivational strategies to involve students in academic activities for improving their grades and overall performance in the subjects. Teachers must make it clear to students, about the types of goals they should set for themselves and should make the students focus on mastering skills and behavior change rather than memorizing material. Teachers need teaching strategies that reduce academic gender differences. They need to encourage all students to achieve to their potential and to provide them with emotional and academic support when needed. Teachers must appreciate students for their achievements whether inconsequential or most important as children who perceive that their teachers said positive things to them have higher self-concepts (Burnett, 1999). There must be a close relationship between teachers and students because when the students like a teacher they experience motivational and achievement benefits. (Montalvo, Mansfield, and Miller, 2007) 
Improvement in learning and achievement is the basic agenda of every education system. It is therefore suggested that an exposure to self-esteem enhancement programmes and enhancement in positive self concept should be made to change students' perceptions of themselves leading to an improvement in learning outcomes. The parents as well as the education authorities should engage in programmes that can motivate the students to improve their academic performance. In short we may conclude in the words of Cassidy (2000) who asserts that achievement motivation appears to take on an important role in terms of the development of identity. This identity may improve the perceptions of students about themselves and about their academic competence.

\section{References}

Abouserie, R. (1995). Self-esteem and achievement motivation as determinants of students' approaches to studying, Studies in Higher Education, 20: 1, 19-26

Akbaş, A., \& Kan, A. (2007). Affective Factors That Influence Chemistry Achievement (Motivation and Anxiety) and the Power of These Factors to Predict Chemistry Achievement-II. Journal of Turkish Science Education, Volume 4, Issue 1.

Barker, K. L., McInerney, D. M., and Dowson, M. (2003). Conceptualising Students' Goals and Self-Concept as Multidimensional and Hierarchically Structured. Paper presented at NZARE AARE, Auckland, New Zealand, November 2003 BAR03775

Bernardo, A. B. I. (2008). Individual and social dimensions of Filipino students' achievement goals, International Journal of Psychology, 43: 5, 886-891

Bong, M., \& Clark, R. E. (1999). Comparison between self-concept and self-efficacy in academic motivation research, Educational Psychologist, 34: 3, 139-153

Broussard, S. C. (2002). The relationship between classroom motivation and academic achievement in first and third graders. Unpublished Masters Thesis. Louisiana State University.

Burnett, P. C. (1999). Children's Self-Talk and Academic Self-Concepts, Educational Psychology in Practice, 15: 3 , $195-200$

Cassidy, T. (2000). Social background, achievement motivation, optimism and health: a longitudinal study, Counseling Psychology Quarterly, 13: 4, 399-412

Chowdhury, A., \& Pati, C. (1997). Effect of Selected Family Variables on Social Preference, Academic Achievement and Self-Concept of Elementary School Children, Early Child Development and Care, 137: 1, $133-143$

Collins, C. J., Hanges, P. J., \& Locke, E. A. (2004). The Relationship of achievement Motivation to Entrepreneurial Behavior: A Meta-Analysis, Human Performance, 17: 1, 95-117

Dai, David Yun, Moon, Sidney M., \& Feldhusen, John F. (1998) Achievement motivation and gifted students: A social cognitive perspective, Educational Psychologist, 33: 2, 45-63

Deci, E. L., \& Ryan, R. M. (2000). Self-determination theory and the facilitation of intrinsic motivation, social development, and well being. American Psychologist, 55(1), 68-78.

Dowson, M., \& McInerney, D. M. (2001). Psychological parameters of students' social and work avoidance goals: A qualitative investigation. Journal of Educational Psychology, 93(1), 35-42.

Elliot, A. J., \& McGregor H. A. (2001). A 2x2 achievement goal framework. Journal of Personality and Social Psychology, 80 501-519

Fontayne, P., Sarrazin, P., \& Famose, J. (2001). Culture and Achievement Motivation in Sport: A Qualitative Comparative Study Between Maghrebian and European French Adolescents. European Journal of Sport Science, vol. 1 , issue 4 .

Hotulainen, R. H. E., \& Schofield, N. J. (2003). Identified Pre-school Potential Giftedness and its Relation to Academic Achievement and Self-concept at the End of Finnish Comprehensive School. High Ability Studies, 14: 1, 55-70

Maehr, M. L. (2008). Culture and achievement motivation, International Journal of Psychology, 43: 5, 917-918

Marsh, H. W. (1990). The structure of academic self-concept: The Marsh/Shavelson model. Journal of Educational Psychology, 82, 623-636

McClelland, D. C. (1985). Human motivation. Chicago:Scott Foresman. 
McClelland, D.C. (1961). The achieving society. Princeton, New Jersey: Van Nostrand.

McClelland, D.C., \& Winter, D.G. (1969). Motivating economic achievement. New York: Free Press.

McInerney, D.M. (1997). Relationship between motivational goals, sense of self, self-concept and cademic achievement for Aboriginal students. 10th Annual Aboriginal Studies Association Conference, University of Western Sydney, Bankstown Campus, Milperra, 12-14 July, 2000.

Noar, S. M., Anderman, E. M., Zimmerman, R. S. \& Cupp, P. K. (2005). Fostering Achievement Motivation in Health Education, Journal of Psychology \& Human Sexuality, 16: 4, 59-76

Ommundsen, Y., Haugen, R., \& Lund, T. (2005). Academic Self-concept, Implicit Theories of Ability, and Self-regulation Strategies, Scandinavian Journal of Educational Research, 49:5, 461-474

Sullivan, Alice. (2009) Academic self-concept, gender and single-sex schooling, British Educational Research Journal, 35: 2, 259-288

Tella, A. (2007). The impact of motivation on student's academic achievement and learning outcomes in mathematics among secondary school students in Nigeria. Eurasia Journal of Mathematics, Science \& Technology Education, 3(2), 154

Tucker, C. M., Zayco, R. A., \& Herman, K. C. (2002). Teacher and child variables as predictors of academic engagement among low-income African American children. Psychology in the Schools, 39(4), 477-488

Wang, J., \& Lin, E. (2008). An Alternative Interpretation of the Relationship between Self-Concept and Mathematics Achievement: Comparison of Chinese and US Students as a Context, Evaluation \& Research in Education, 21: 3,154-174

Weiner, B. (1986). An attributional theory of motivation and emotion. New York: Springer-Verlag.

Wilkins, N. J. (2006). Why try? Achievement motivation and perceived academic climate among latino youth Unpublished Master's Thesis. Georgia State University.

Zanobini, M., \& Usai, M. C. (2002). Domain-specific Self-concept and Achievement Motivation in the Transition from Primary to Low Middle School, Educational Psychology, 22: 2, 203-17

Woollfolk, A. (2004). Educational psychology. Boston, MA: Allyn \& Bacon.

Table 1. Pearson $r$ among the Self Concept, Achievement Motivation, and Academic Achievement ( $\mathrm{N}=336)$

\begin{tabular}{llcccccc}
\hline $\mathrm{S}$ & \multicolumn{1}{c}{ Variables } & 1 & 2 & 3 & 4 & 5 & 6 \\
\hline 1 & Self Concept of English & - & & & & \\
2 & Self Concept of Mathematics & $.302^{* *}$ & - & & & \\
3 & Mathematics Achievement & & $.535^{* *}$ & - & & \\
4 & English Achievement & $.373^{* *}$ & & $.581^{* *}$ & - & \\
5 & Mastery Goals & $.370^{* *}$ & $.285^{* *}$ & $.424^{* *}$ & $.403^{* *}$ & - & \\
6 & Performance Goals & $.385^{* *}$ & $.307^{* *}$ & $.420^{* *}$ & $.398^{* *}$ & $.656^{* *}$ & - \\
7 & Social Goals & $.206^{* *}$ & $.154^{* *}$ & $.240^{* *}$ & $.297^{* *}$ & $.530^{* *}$ & $.490^{* *}$ \\
\hline
\end{tabular}

**. Correlation is significant at the 0.01 level (2-tailed).

The Table above shows the correlations of the self concept of English and mathematics and all three dimensions of achievement motivation and Academic achievement of mathematics are significant at the 0.01 level (2-tailed). Academic achievement of English and the academic achievement of mathematics are highly and significantly correlated at 0.01 level (2-tailed). The relationship among achievement of English and mathematics and three variables of achievement motivation is also significant. The interrelationship between the three variables of achievement motivation is very significant, strong and positive. 
Table 2. Multiple Regression Analysis; Self Concept, Mastery Goals, Performance Goals, Social Goals and Academic Achievement in Mathematics

\begin{tabular}{lcccccccc}
\hline Predictors & $\mathrm{B}$ & $t$-value & $p$ & $S E($ est. $)$ & $F$ & Sig. & $\mathrm{R}$ & $\mathrm{R}-$ Square \\
\hline Self Concept & .430 & 9.389 & .000 & .139 & & & & \\
Social Goals & .013 & -.244 & .807 & .382 & 50.872 & .000 & .617 & .381 \\
Mastery Goals & .202 & 3.315 & .001 & .275 & & & & \\
Performance Goals & .162 & 2.722 & .007 & .179 & & & & \\
\hline
\end{tabular}

Regression Analysis for self concept and achievement motivation as Predictor of academic achievement in mathematics is presented in table 3. The analysis of the data resulted in R-Square of .381, which implies that the self concept and achievement motivation accounted for 37 percent of the variation in achievement of mathematics. Since the $\mathrm{F}(4,331)=50.872, \mathrm{p}=.000$, was significance, so it means that self concept and achievement motivation contributed significantly in the academic achievement of mathematics. It was concluded that individual variables, self concept $\mathrm{t}(336)=9.389, \mathrm{p}=.000$, mastery goals, $\mathrm{t}(336)=3.315, \mathrm{p}=.001$, and performance goals, $\mathrm{t}(336)=2.722$, $\mathrm{p}=.007$ made a significant contribution and can be used as predictor of academic achievement.

Table 3. Multiple Regression Analysis; Self Concept, Mastery Goals, Performance Goals, Social Goals and Academic Achievement in English

\begin{tabular}{lcccccccc}
\hline Predictors & $\mathrm{B}$ & $t$-value & $p$ & $S E($ est.) & $F$ & Sig. & $\mathrm{R}$ & R-Square \\
Self Concept & .155 & 4.429 & .000 & .208 & & & & \\
Social Goals & .082 & 1.410 & .159 & .459 & 26.457 & .000 & .492 & .242 \\
Mastery Goals & .172 & 2.543 & .011 & .333 & & & & \\
Performance Goals & .155 & 2.328 & .021 & .217 & & & &
\end{tabular}

Regression Analysis for self concept and achievement motivation as Predictor of academic achievement in English is presented in the above table. The analysis of the data resulted in R-Square of .242, which implies that the self concept and achievement motivation accounted for 24 percent of the variation in achievement of English. Since the $\mathrm{F}(4,331) 26.457, \mathrm{p}=.000$, was significance, so it means that self concept and achievement motivation contributed significantly in the academic achievement of mathematics. It was concluded that individual variables, self concept of English, t (336) $=4.429, \mathrm{p}=.000$, mastery goals, $\mathrm{t}(336)=2.543, \mathrm{p}=.011$, and performance goals, $\mathrm{t}(336)=2.328$, $\mathrm{p}=.021$ made a significant contribution and can be used as predictor of academic achievement. 
Table 4. N, Mean, SD and $t$ tests for Fender Differences of Achievement Motivation, Self Concept and Academic Achievement

\begin{tabular}{|c|c|c|c|c|c|c|c|c|}
\hline Variables & Gender & $\mathrm{N}$ & Means & Std.Dev. & $\begin{array}{c}\text { Std. Error } \\
\text { Mean }\end{array}$ & $\mathrm{t}$ & df & Sig. \\
\hline \multirow{2}{*}{$\begin{array}{l}\text { English } \\
\text { Concept }\end{array}$} & Male & 164 & 24.2683 & 3.78907 & .29588 & \multirow{2}{*}{-5.707} & \multirow{2}{*}{334} & \multirow{2}{*}{.000} \\
\hline & Female & 172 & 26.5174 & 3.43268 & .26174 & & & \\
\hline \multirow{2}{*}{$\begin{array}{l}\text { Mathematics Self } \\
\text { Concept }\end{array}$} & Male & 164 & 23.9451 & 4.93050 & .38501 & \multirow[t]{2}{*}{-4.024} & \multirow[t]{2}{*}{334} & \multirow[t]{2}{*}{.000} \\
\hline & Female & 172 & 25.8779 & 3.82851 & .29192 & & & \\
\hline \multirow[t]{2}{*}{ Social Goals } & Male & 164 & 12.6220 & 1.82108 & .14220 & \multirow[t]{2}{*}{-1.909} & \multirow[t]{2}{*}{334} & \multirow[t]{2}{*}{.057} \\
\hline & Female & 172 & 13.0116 & 1.91635 & .14612 & & & \\
\hline \multirow[t]{2}{*}{ Mastery Goals } & Male & 164 & 21.3902 & 3.19031 & .24912 & \multirow[t]{2}{*}{-4.193} & \multirow[t]{2}{*}{334} & \multirow[t]{2}{*}{.000} \\
\hline & Female & 172 & 22.7442 & 2.71959 & .20737 & & & \\
\hline \multirow{2}{*}{$\begin{array}{l}\text { Performance } \\
\text { goals }\end{array}$} & Male & 164 & 33.0488 & 4.58834 & .35829 & \multirow[t]{2}{*}{-4.629} & \multirow[t]{2}{*}{334} & \multirow[t]{2}{*}{.000} \\
\hline & Female & 172 & 35.2849 & 4.26535 & .32523 & & & \\
\hline \multirow{2}{*}{$\begin{array}{l}\text { Mathematics } \\
\text { Achievement }\end{array}$} & Male & 164 & 57.1646 & 13.76368 & 1.07476 & \multirow[t]{2}{*}{-2.987} & \multirow[t]{2}{*}{334} & \multirow[t]{2}{*}{.003} \\
\hline & Female & 172 & 61.5814 & 13.34163 & 1.01729 & & & \\
\hline \multirow{2}{*}{$\begin{array}{l}\text { English } \\
\text { Achievement }\end{array}$} & Male & 164 & 55.2317 & 14.64031 & 1.14322 & \multirow[t]{2}{*}{-2.469} & \multirow[t]{2}{*}{334} & \multirow[t]{2}{*}{.014} \\
\hline & Female & 172 & 59.2151 & 14.91752 & 1.13745 & & & \\
\hline
\end{tabular}

Table 4 shows the gender differences across all the variables involved in the study. The mean gender difference for self concept of English is significant $(t=-5.707, p<.01)$ at 0.01 level of significance. This difference is in favour of girls having strong self perceptions as compared to boys. Self concept for Mathematics $(t=-4.024, p<.01)$ was also significant and again in favour of girls. The gender differences for performance goals $(t=-4.639, p<0.01)$ and mastery goals $(\mathrm{t}=-4.193, \mathrm{p}<0.01)$ are also significant but non-significant for social goals $(\mathrm{t}=-1.99, \mathrm{p}>0.05)$.

In terms of Academic achievement in English and mathematics the mean differences for both the variables were significant i.e. English achievement $(t=-2.469, \mathrm{p}<0.05)$ and mathematics achievement $(\mathrm{t}=2.987, \mathrm{p}<0.05)$. because there were significant gender differences in all the variables except social goal so it is concluded that there is a significant difference in self concept of English and mathematics, Academic achievement and performance goals and mastery goals of male and female students. 